\title{
Phagocytosis of Piliated and Non-piliated Corynebacterium renale by Murine Polymorphonuclear Leukocytes
}

\author{
Takayuki KUBOTA, and Ryo YANAGAWA \\ Department of Hygiene and Microbiology, Faculty of Veterinary Medicine, Hokkaido University, Sapporo 060, Japan
}

(Received 21 Septebmer 1987/Accepted 24 October 1987)

\begin{abstract}
Uptake by mouse polymorphonuclear leukocytes (PMNs) of piliated $\left(\mathrm{P}^{+}\right)$and non-piliated $\left(\mathrm{P}^{-}\right)$bacteria of Corynebacterium renale strain No. 115 was studied. $\mathrm{P}^{+}$bacteria were significantly less phagocytized than $\mathrm{P}^{-}$bacteria by PMNs in the absence of opsonins, in the presence of $5 \%$ complement alone, and in the presence of either anti-pili serum alone, anti- $\mathrm{P}^{+}$bacteria serum alone or anti- $\mathrm{P}^{-}$ bacteria serum alone. Uptake of $\mathrm{P}^{+}$bacteria was enhanced and became nearly equal to $\mathrm{P}^{-}$bacteria in the presence of anti-pili serum plus complement and in the presence of anti- $\mathrm{P}^{+}$bacteria serum plus complement. The anti-pili monoclonal antibodies $16 / 5$ and $13 / 4$ were opsonic, regardless of the presence of complement, for $\mathrm{P}^{+}$but not $\mathrm{P}^{-}$bacteria, but there was less effect than that of anti-pili polyclonal antibody plus complement. Uptake of $\mathrm{P}^{-}$bacteria in the presence of opsonins was similar to that in the absence of opsonins.-KEY wORDS: Corynebacterium renale, non-piliated bacterium, piliated bacterium, phagocytosis, polymorphonuclear leukocyte.
\end{abstract}

Jpn.J. Vet. Sci. 50(1): 199-207, 1988

Infiltration of leukocytes in urinary organs is one of the main features of Corynebacterium renale infection in cows $[8$, 16]. Masses of polymorphonuclear leukocytes (PMNs) were observed in the mucous layer of the urinary bladder, ureter and kidney $[5,7,8,16]$. The urinary sediment contained PMNs, red cells and diphteroids in large numbers $[8,16]$.

The previous report using macrophages revealed that piliated $\left(\mathrm{P}^{+}\right)$bacteria of $C$. renale were less phagocytized than nonpiliated $\left(\mathrm{P}^{-}\right)$bacteria in the absence of opsonins, but were more readily phagocytized than $\mathrm{P}^{-}$bacteria in the presence of anti-pili antibodies [12]. Phagocytosis of $\mathrm{P}^{+}$ and $\mathrm{P}^{-}$bacteria of $C$. renale by $\mathrm{PMNs}$, however, has not been studied.

Ability of PMNs to phagocytize $\mathrm{P}^{+}$and $\mathrm{P}^{-}$bacteria has been shown in some bacteria. PMNs phagocytized effectively piliated Neisseria gonorrhoeae in the presence of anti-pili antibodies [9], but not in the absence of anti-pili antibodies [2-4, 19]. PMNs phagocytized more effectively Escherichia coli possessing type 1 pili than $E$. coli lacking pili in the absence of opsonins $[1,13$, 14, 21]. Piliated Haemophilus influenzae type $b$ was more readily phagocytized by PMNs than non-piliated $H$. influenzae type $\mathrm{b}$ in the presence of normal human serum and in the presence of anti-pili serum [22]. These findings showed that phagocytosis of piliated bacteria by PMNs is different among bacterial species.

In the present study, the susceptibility of C. renale piliated and non-piliated clones to phagocytosis by mouse PMNs in the absence and presence of opsonins was compared. The results were described below.

\section{MATERIALS AND METHODS}

Bacteria: C. renale strain No. $115, \mathrm{P}^{+}$and $\mathrm{P}^{-}$bacteria [15] were used. Bacteria were stored at $-80^{\circ} \mathrm{C}$ before use as described previously [12]. For each experiment, a vial was thawed and portions $\left(1.3 \times 10^{9} \mathrm{CFU}\right)$ were inoculated into $40 \mathrm{ml}$ of nutrient broth containing $10 \mu \mathrm{Ci}$ of $\left[5,6-{ }^{3} \mathrm{H}\right]$ uridine 
(specific activity, $47.1 \mathrm{Ci} / \mathrm{mmol}$; New England Nuclear, Boston, Mass., U. S. A.). After growth for $24 \mathrm{hr}$ at $37^{\circ} \mathrm{C}$, the bacteria were washed three times in phosphate buffered saline (PBS), pH 7.4, and suspended in Hanks' balanced salt solution (HBSS) containing $1 \%$ gelatin [17], $10 \mathrm{mM}$ HEPES (N-2-hydroxyethylpiperazine-N'-2-ethanesulfonic acid) (Nakarai Chemicals Ltd., Kyoto, Japan) and $5 \mathrm{U} / \mathrm{m} l$ heparin (Wako Pure Chemicals Industries Ltd., Osaka, Japan). Non-labeled culture was prepared similarly. The number of $\left[{ }^{3} \mathrm{H}\right]$-labeled bacteria was determined by counting nonlabeled bacteria in a hemocytometer as described previously [12].

Leukocytes: Female ddY mice, 6-9 weeks old, were injected intraperitoneally with 2.5 $\mathrm{ml}$ of $5 \%$ proteose peptone (Difco Laboratories, Detroit, Mich., U. S. A.) and 5\% starch (Kanto Chemical Corp., Tokyo, Japan) per mouse to stimulate granulocyte infiltration. Mice were sacrificed $12 \mathrm{hr}$ after intraperitoneal injection. Peritoneal cells were harvested with HBSS. Cells were washed and suspended in $10 \%$ calf serumRPMI 1640 medium (containing 10\% calf serum, $1 \%$ gelatin, $10 \mathrm{mM}$ HEPES and 5 $\mathrm{U} / \mathrm{m} l$ heparin). Cells were pipetted into a petri dish and incubated at $37^{\circ} \mathrm{C}$ for $90 \mathrm{~min}$ to remove macrophages. After incubation, cells were washed with HBSS. Leukocytes were removed from the petri dish and suspended in $10 \%$ calf serum-RPMI 1640 medium. The leukocyte population contained $75.5 \%$ PMNs, 5.5\% macrophages and $18.5 \%$ lymphocytes.

Complement: Sera from 5 guinea pigs were pooled and used as complement. Complement titer was 180 the $50 \%$ hemolytic unit of complement $\left(\mathrm{CH}_{50}\right)$ according to the method of Mayer [10]. Inactivated complement was prepared by heating the complement at $56^{\circ} \mathrm{C}$ for $30 \mathrm{~min}$.

Antisera: Rabbit antisera against $C$. renale No. $115 \mathrm{P}^{+}$and $\mathrm{P}^{-}$bacteria were prepared as described previously [6]. Antipili serum was prepared by the method of Honda et al. [6]. Briefly, anti-strain $115 \mathrm{P}^{+}$ bacteria serum was absorbed with $\mathrm{P}^{-}$bacteria at $37^{\circ} \mathrm{C}$ for $2 \mathrm{hr}$, centrifuged and filtrated through a membrane filter (Toyo Roshi kaisha Ltd., Tokyo, Japan, $450 \mathrm{~nm}$ pore size). The agglutination titers of anti$\mathrm{P}^{+}$bacteria serum, anti- $\mathrm{P}^{-}$bacteria serum and anti-pili serum were, respectively, 1:5,120, 1:2, 560 and 1:320. All antisera and normal rabbit serum (NRS) were heat inactivated at $56^{\circ} \mathrm{C}$ for $30 \mathrm{~min}$. Anti-pili serum, anti- $\mathrm{P}^{+}$bacteria serum and anti- $\mathrm{P}^{-}$ bacteria serum were used as opsonins at the subagglutination concentrations $(1: 10,240$ for anti- $\mathrm{P}^{+}$bacteria serum, 1:5,120 for anti- $\mathrm{P}^{-}$bacteria serum and 1:640 for antipili serum).

Monoclonal antibodies: Two anti-pili monoclonal antibodies, $16 / 5$ and $13 / 4$, were described previously [11]. Monoclonal antibody $16 / 5$ inhibited the adhesion to the epithelial cells of the bovine vulva, while monoclonal antibody $13 / 4$ did not. Both antibodies were immunoglobulin G1 class. The titers of $16 / 5$ and $13 / 4$ were, respectively, $1: 12,800$ and $1: 64$ by the agglutination test, and $1: 104,857,600$ and $1: 1,638,400$ by ELISA. Ascitic fluid containing monoclonal antibodies and ascitic fluid were heat inactivated at $56^{\circ} \mathrm{C}$ for $30 \mathrm{~min}$.

To equalize the amount of antibodies bound to the antigen, that is purified pili of C. renale No. 115, the concentration of each monoclonal antibody was adjusted to optical density 1.5 by ELISA. Concentrations of anti-pili monoclonal antibodies $16 / 5$ and $13 / 4$ corresponded to optical density 1.5 and were, respectively $1: 54,000$ and $1: 100$. None of the final concentrations of monoclonal antibodies used caused bacterial agglutination.

Phagocytosis assay: The number of bacteria was adjusted to $10^{7}, 5 \times 10^{8}$ and $10^{8}$ per $50 \mu l$ of HBSS. Leukocytes $\left(10^{6}\right.$ cells $\left./ 50 \mu l\right)$, 
bacterial suspension $(50 \mu l)$ and opsonins $(100 \mu l)$ were mixed in siliconized tubes. When opsonins or cells were absent, the same volume of RPMI 1640 medium (containing $1 \%$ gelatin, $10 \mathrm{mM}$ HEPES and 5 $\mathrm{U} / \mathrm{m} l$ heparin) was added. Phagocytosis was performed as described previously [23]. Immediately after cells, bacteria and opsonins were mixed, the tubes were incubated at $37^{\circ} \mathrm{C}$ in a shaking water bath. Triplicate tubes were removed from the incubator at 5, 15,30 and $60 \mathrm{~min}$ intervals. Then $3 \mathrm{ml}$ of ice-cold PBS (containing heparin) were added to the tubes. The tubes were centrifuged at $45 \times g$ for $10 \mathrm{~min}$ and leukocyte pellets were washed three times with icecold PBS. After cells were washed, one hundred microliters of $0.03 \mathrm{mM}$ Tris- $\mathrm{HCl}$ buffer containing 2\% Triton $\mathrm{X}-100$ were added to leukocyte pellets and cells were placed in scintillation vials. Five $\mathrm{m} l$ of scintillation liquid [Clear sol I (Nakarai)] were added to the vials and samples were counted in a liquid scintillation counter (LSC-900 Aloka Corp. Ltd., Tokyo, Japan). Control samples (bacteria only) were taken after $1 \mathrm{hr}$ incubation, washed in ice-cold PBS three times at $45 \times g$ for $10 \mathrm{~min}$ and counted in a liquid scintillation counter in the same manner as the leukocytebacteria sample described above. To determine the total bacterial cpm, samples (bacteria plus PMNs and bacteria only) were taken at the end of the assay period, $3 \mathrm{ml}$ of PBS were added to them, and they were centrifuged at $1,500 \times \mathrm{g}$ for $30 \mathrm{~min}$. Pellets were counted in a liquid scintillation counter. An average of the triplicate values was used for all calculations. The percentage of the total bacterial population that was leukocyte-associated at a given sampling time (percent uptake) was calculated with the following formula [23]:

$$
\begin{aligned}
& \% \text { Uptake }= \\
& \left\{\frac{\mathrm{cpm} \text { in the pellet (bacteria }+ \text { PMNs, } 45 \times g 10 \mathrm{~min})}{\mathrm{cpm} \text { in the pellet (bacteria }+ \text { PMNs, } 1,500 \times g 30 \mathrm{~min})}\right. \\
& \left.-\frac{\mathrm{cpm} \text { in the pellet (bacteria, } 45 \times \mathrm{g} 10 \mathrm{~min})}{\text { cpm in the pellet (bacteria, } 1,500 \times \mathrm{g} 30 \mathrm{~min})}\right\} \times 100
\end{aligned}
$$

The phagocytosis of $\mathrm{P}^{+}$and $\mathrm{P}^{-}$bacteria in the absence of opsonins was also confirmed morphologically by Giemsa stain.

Statistical analysis: Student's $t$ test was used to assess significance. Data to assess significance were obtained from samples incubated for $1 \mathrm{hr}$.

\section{RESULTS}

1. Phagocytosis by PMNs of $\mathrm{P}^{+}$and $\mathrm{P}^{-}$ bacteria in the absence of opsonins

A preliminary experiment without opsonins using bacteria/PMN ratio of $10: 1$ showed that the number of phagocytized $\mathrm{P}^{+}$ and $\mathrm{P}^{-}$bacteria by $\mathrm{PMNs}$ reached a maximum at $1 \mathrm{hr}$ incubation and was similar until $3 \mathrm{hr}$ incubation (data not shown). Therefore $1 \mathrm{hr}$ incubation was used for all subsequent experiments.

Phagocytosis of labeled $\mathrm{P}^{+}$and $\mathrm{P}^{-}$bacteria was expressed in the present study with percent uptake and also confirmed morphologically by Giemsa stain of samples processed after $1 \mathrm{hr}$ of incubation with PMNs in the absence of opsonins. The number of phagocytized bacteria at $1 \mathrm{hr} 1.6$ organisms/ PMN for $\mathrm{P}^{+}$bacteria and 4.1 organisms/ PMN for $\mathrm{P}^{-}$bacteria.

A comparison was made of the susceptibility of $\mathrm{P}^{+}$and $\mathrm{P}^{-}$bacteria to the phagocytosis of PMNs in the absence of opsonins (Fig. 1). $\mathrm{P}^{-}$bacteria were phagocytized at a significantly higher rate than $\mathrm{P}^{+}$bacteria $(\mathrm{P}<0.01)$ in the absence of opsonins, at the bacteria/PMN ratios of 10:1, 50:1 and 100:1. The bacteria/PMN ratios of $10: 1$ and $50: 1$ were found to be more appropriate than 


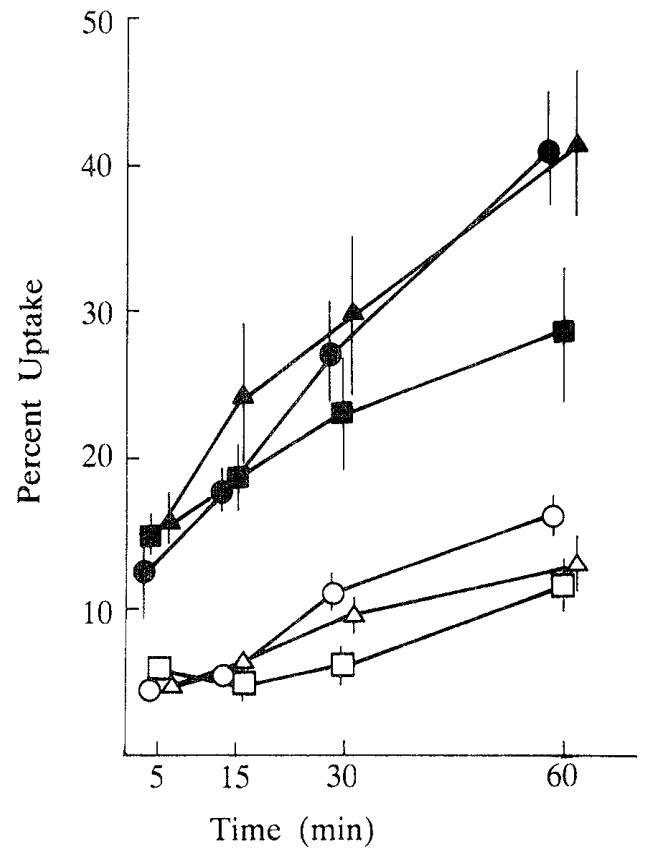

Fig. 1. Phagocytosis $\mathrm{P}^{+}$and $\mathrm{P}^{-}$bacteria in the absence of opsonins. Bacteria/PMN ratios were $10: 1$ $\left(\mathrm{P}^{+} \mathrm{O}, \mathrm{P}^{-}\right), 50: 1\left(\mathrm{P}^{+} \Delta, \mathrm{P}^{-} \Delta\right)$ and $100: 1\left(\mathrm{P}^{+} \square\right.$, $\left.\mathrm{P}^{-}\right)$. Data are from a single experiment tested in triplicate. Data shown are mean \pm standard error (brackets).

that of $100: 1$ as phagocytosis was obviously reduced with bacteria/PMN ratio of $100: 1$ (Fig. 1). Phagocytosis by PMNs at the bacteria/PMN ratios of $10: 1$ and $50: 1$ was not so different. In order to demonstrate clearly the uptake of $\mathrm{P}^{+}$bacteria in the presence of opsonins, bacteria/PMN ratio of $10: 1$ was thought preferable to that of $50: 1$ for the following reason. The ratio of percent uptake of $\mathrm{P}^{+}$bacteria in the absence of opsonin to that in the presence of each antiserum alone was found to be more pronounced with the bacteria/PMN ratio of $10: 1$ than with the bacteria/PMN ratio of $50: 1$, which will be described below (Item 3 of results). Therefore, the bacteria/PMN ratio of 10:1 was used for all subsequent experiments.

2. Phagocytosis by $\mathrm{PMNs}$ of $\mathrm{P}^{+}$and $\mathrm{P}^{-}$ bacteria in the presence of only complement as opsonin

Uptake of $\mathrm{P}^{+}$and $\mathrm{P}^{-}$bacteria opsonized with various concentrations of complement alone was compared. Percent uptake of $\mathrm{P}^{+}$ bacteria at $20,10,5$ or $0 \%$ concentrations of complement was $13.1 \pm 2.1,14.1 \pm 3.7$, $12.2 \pm 1.8$ or $8.3 \pm 1.8$, respectively, and was similar to each other (not significantly different). Percent uptake of $\mathrm{P}^{-}$bacteria at 20 , 10,5 or $0 \%$ concentrations of complement was $38.8 \pm 2.7,40.6 \pm 5.0,43.1 \pm 5.6$ or $33.0 \pm 5.9$, respectively, and was similar to each other (not significantly different). Heat inactivated complement was not opsonic. Five $\%$ concentration of complement was thus used in the following experiments. In the presence of $5 \%$ concentration of complement, uptake of $\mathrm{P}^{-}$bacteria was significantly greater than that of $\mathrm{P}^{+}$bacteria $(\mathrm{P}<0.005)$.

3. Phagocytosis by $\mathrm{PMNs}$ of $\mathrm{P}^{+}$and $\mathrm{P}^{-}$ bacteria in the presence of anti-pili serum alone, anti- $\mathrm{P}^{+}$bacteria serum alone and anti- $\mathrm{P}^{-}$bacteria serum alone as opsonin

In the presence of subagglutination concentrations of anti-pili serum alone, anti- $\mathrm{P}^{+}$ bacteria serum alone and anti- $\mathrm{P}^{-}$bacteria serum, $\mathrm{P}^{-}$bacteria were phagocytized significantly more than $\mathrm{P}^{+}$bacteria $(\mathrm{P}<0.05$ for anti-pili serum, $\mathrm{P}<0.01$ for anti- $\mathrm{P}^{+}$bacteria serum and $\mathrm{P}<0.025$ for anti- $\mathrm{P}^{-}$bacteria serum) (Fig. 2).

Uptake of phagocytized $\mathrm{P}^{+}$bacteria in the presence of anti-pili serum alone, anti- $\mathrm{P}^{+}$ bacteria serum alone, anti- $\mathrm{P}^{-}$bacteria serum alone or NRS alone, respectively, did not differ significantly among each serum. Uptake of $\mathrm{P}^{-}$bacteria in the presence of anti-pili serum alone, anti- $\mathrm{P}^{+}$bacteria serum alone, anti- $\mathrm{P}^{-}$bacteria serum alone or NRS alone was, respectively, not significantly different and was similar among each serum. Uptake of $\mathrm{P}^{+}$and $\mathrm{P}^{-}$bacteria in the presence of NRS alone was similar to that in the absence of NRS (without opsonins).

The ratio of percent uptake of $\mathrm{P}^{+}$bacteria in the presence of each antiserum (anti-pili serum, anti- $\mathrm{P}^{+}$bacteria serum or anti- $\mathrm{P}^{-}$ 


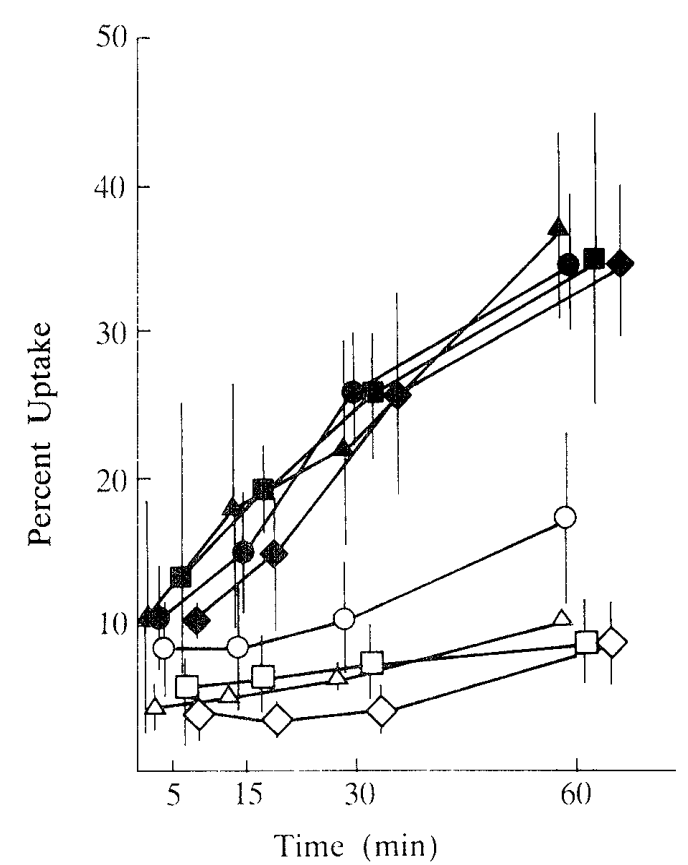

Fig. 2. Phagocytosis of $\mathrm{P}^{+}$and $\mathrm{P}^{-}$bacteria in the presence of anti-pili serum alone $\left(\mathrm{P}^{+} \mathrm{O}, \mathrm{P}^{-}\right)$, anti- $\mathrm{P}^{+}$bacteria serum alone $\left(\mathrm{P}^{+} \triangle, \mathrm{P}^{-} \mathbf{\Lambda}\right)$, anti- $\mathrm{P}^{-}$ bacteria serum alone $\left(\mathrm{P}^{+} \square, \mathrm{P}^{-}\right.$圆) and NRS alone $\left(\mathrm{P}^{+} \diamond, \mathrm{P}^{-}\right)$as opsonins. Antisera were used at subagglutination concentrations. Data are from a single experiment tested in triplicate. Data shown are mean \pm standard error (brackets).

bacteria serum) alone to that in the absence of opsonin was $2.0(17.5 / 8.7), 1.2(10.4 / 8.7)$, or $1.0(8.7 / 8.7)$ with the bacteria/PMN ratio of $10: 1$ and $1.5(18.4 / 12.5), 1.1(13.2 / 12.5)$ or $1.1(14.0 / 12.5)$ with the ratio of $50: 1$. Thus, the ratio of percent uptake of $\mathrm{P}^{+}$ bacteria with the bacteria/PMN ratio of $10: 1$ was larger than that with the bacteria/PMN ratio of $50: 1$. Uptake of $\mathrm{P}^{+}$bacteria was more pronounced with the ratio of $10: 1$ than with that of $50: 1$.

4. Phagocytosis by $\mathrm{PMNs}$ of $\mathrm{P}^{+}$and $\mathrm{P}^{-}$ bacteria in the presence of anti-pili, anti- $\mathrm{P}^{+}$ bacteria and anti- $\mathrm{P}^{-}$bacteria sera, respectively, plus complement as opsonins

In the presence of anti-pili serum and anti- $\mathrm{P}^{+}$bacteria serum, respectively, plus complement, $\mathrm{P}^{+}$bacteria were more readily phagocytized by PMNs than they were in the presence of each antiserum alone, and uptake of $\mathrm{P}^{+}$bacteria was nearly equal to

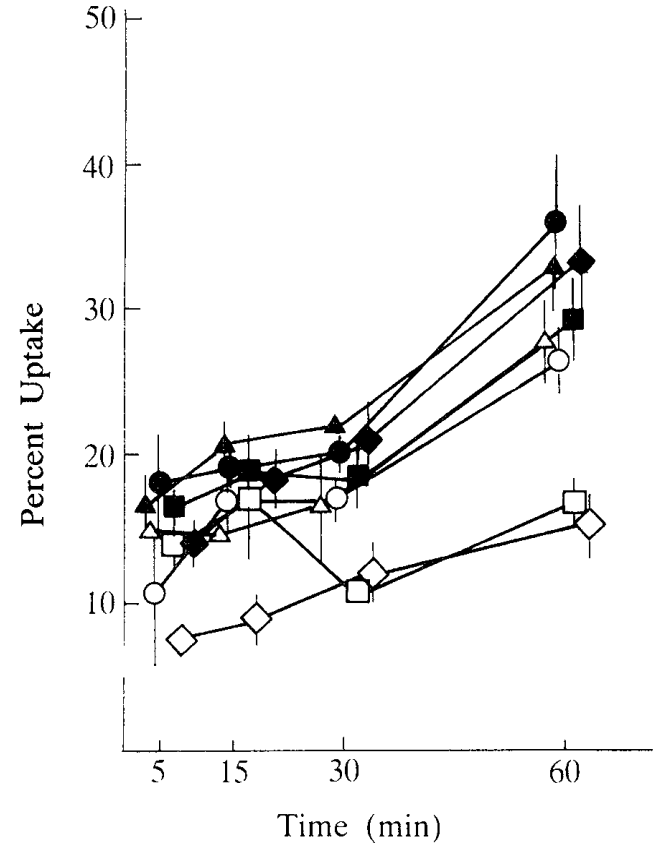

Fig. 3. Phagocytosis of $\mathrm{P}^{+}$and $\mathrm{P}^{-}$bacteria in the presence of anti-pili serum $\left(\mathrm{P}^{+} \mathrm{O}, \mathrm{P}^{-} \mathrm{O}\right)$, anti- $\mathrm{P}^{+}$ bacteria serum $\left(\mathrm{P}^{+} \triangle, \mathrm{P}^{-} \boldsymbol{\Delta}\right)$, anti- $\mathrm{P}^{-}$bacteria serum $\left(\mathrm{P}^{+} \triangle, \mathrm{P}^{-} \mathbf{\Delta}\right)$ and NRS $\left(\mathrm{P}^{+} \diamond, \mathrm{P}^{-} \diamond\right)$, respectively, plus complement as opsonins. Antisera were used at subagglutination concentrations. Data are from a single experiment tested in triplicate. Data shown are mean \pm standard error (brackets).

that of $\mathrm{P}^{-}$bacteria (Fig. 3). In the presence of anti- $\mathrm{P}^{-}$bacteria serum and NRS, respectively, plus complement, $\mathrm{P}^{-}$bacteria were more readily phagocytized than $\mathrm{P}^{+}$bacteria $(\mathrm{P}<0.05$ and $\mathrm{P}<0.01$, respectively).

Uptake of $\mathrm{P}^{+}$bacteria in the presence of each antiserum plus complement was compared. Uptake of phagocytized $\mathrm{P}^{+}$bacteria in the presence of anti-pili serum plus complement or that in the presence of anti- $\mathrm{P}^{+}$bacteria serum plus complement was, respectively, not significantly different among each serum, and was significantly greater than that in the presence of anti- $\mathrm{P}^{-}$ bacteria serum plus complement $(\mathrm{P}<0.01)$ or in the presence of NRS plus complement $(\mathrm{P}<0.01)$. There was no significant difference between the uptake of $\mathrm{P}^{+}$bacteria in the presence of anti- $\mathrm{P}^{-}$bacteria serum plus complement and that in the presence of NRS plus complement. 


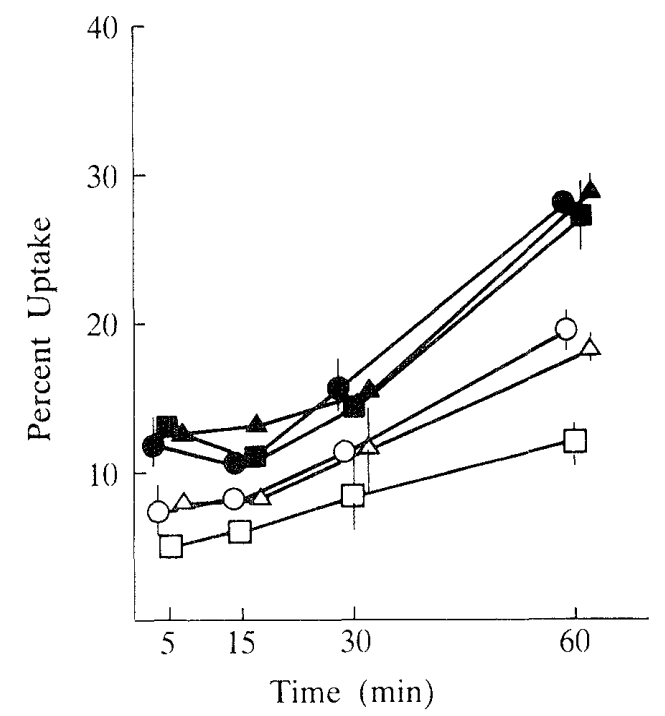

Fig. 4. Phagocytosis of $\mathrm{P}^{+}$and $\mathrm{P}^{-}$bacteria in the presence of anti-pili monoclonal antibodies 16/5 alone $\left(\mathrm{P}^{+} \mathrm{O}, \mathrm{P}^{-}\right), 13 / 4\left(\mathrm{P}^{+} \triangle, \mathrm{P}^{-} \Delta\right)$ and normal ascitic fluid alone $\left(\mathrm{P}^{+} \square, \mathrm{P}^{-}\right)$as opsonins. To equalize the amount of antibodies to antigen, purified pili of $C$. renale, the concentration of each antibody was adjusted by ELISA to optical density 1.5. Data are from a single experiment tested in triplicate. Data shown are mean \pm standard error (brackets).

Uptake of $\mathrm{P}^{-}$bacteria in the presence of anti-pili serum plus complement, anti- $\mathrm{P}^{+}$ bacteria serum plus complement or anti- $\mathrm{P}^{-}$ bacteria serum plus complement was, respectively, not significantly different and was similar to that in the presence of NRS plus complement. Uptake of $\mathrm{P}^{+}$and $\mathrm{P}^{-}$ bacteria in the presence of NRS plus complement was similar to that in the absence of NRS (without opsonins).

5. Phagocytosis of $\mathbf{P}^{+}$and $\mathrm{P}^{-}$bacteria in the presence of anti-pili monoclonal antibodies as opsonins

$\mathrm{P}^{-}$bacteria were more readily phagocytized than $\mathrm{P}^{+}$bacteria in the presence of anti-pili monoclonal antibodies $16 / 5$ alone, $13 / 4$ alone and normal ascitic fluid $(\mathrm{P}<0.05$, $\mathrm{P}<0.05$ and $\mathrm{P}<0.05$, respectively) (Fig. 4). Uptake of $\mathrm{P}^{+}$bacteria in the presence of anti-pili monoclonal antibody $16 / 5$ alone or $13 / 4$ alone was significantly greater than the uptake of $\mathrm{P}^{+}$bacteria in the presence of

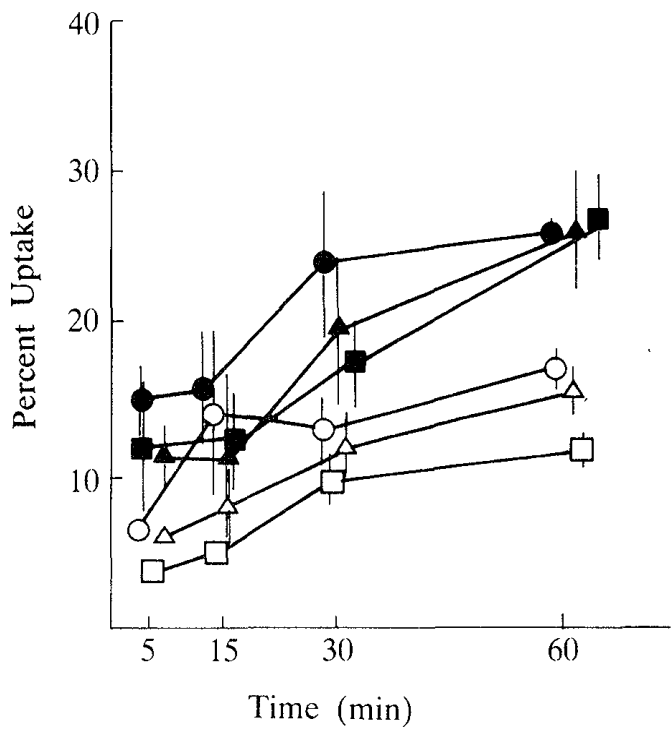

Fig. 5. Phagocytosis of $\mathrm{P}^{+}$and $\mathrm{P}^{-}$bacteria in the presence of anti-pili monoclonal antibodies 16/5 $\left(\mathrm{P}^{+} \mathrm{O}, \mathrm{P}^{-}\right), 13 / 4\left(\mathrm{P}^{+} \Delta, \mathrm{P}^{-} \mathbf{A}\right)$ and normal ascitic fluid $\left(\mathrm{P}^{+} \square, \mathrm{P}^{-}\right)$, respectively, plus complement as opsonins. To equalize the amount of antibodies to antigen, purified pili of $C$. renale, the concentration of each antibody was adjusted by ELISA to optical density 1.5. Data are from a single experiment testes in triplicate. Data shown are mean \pm standard error (brackets).

normal ascitic fluid $(\mathrm{P}<0.025)$. Uptake of $\mathrm{P}^{-}$bacteria in the presence of anti-pili monoclonal antibody $16 / 5$ or $13 / 4$ was similar to uptake in the presence of normal ascitic fluid. Uptake of $\mathrm{P}^{+}$and $\mathrm{P}^{-}$bacteria in the presence of normal ascitic fluid or normal ascitic fluid plus complement was similar to those without opsonins, respectively.

When anti-pili monoclonal antibodies 16/ $5,13 / 4$ and normal ascitic fluid, respectively, plus complement were used, $\mathrm{P}^{-}$bacteria were more readily phagocytized than $\mathrm{P}^{+}$ bacteria $(\mathrm{P}<0.025, \mathrm{P}<0.025$ and $\mathrm{P}<0.01$, respectively) (Fig. 5). Uptake of $\mathrm{P}^{+}$bacteria in the presence of monoclonal antibody $16 / 5$ or $13 / 4$, respectively, plus complement was similar to uptake in the presence of anti-pili monoclonal antibodies alone. Uptake of $\mathrm{P}^{-}$ bacteria in the presence of anti-pili monoclonal antibody $16 / 5$ or $13 / 4$, respectively, plus complement was similar to uptake in 
the presence of normal ascitic fluid plus complement.

$\left[{ }^{3} \mathrm{H}\right]$ uptake $/ 10^{6} \mathrm{PMNs}$ was compared with the number of organisms/PMN: in $\mathrm{P}^{+}$bacteria, $333.2 \mathrm{cpm}$ corresponded to 0.5 organisms/PMN and $725.4 \mathrm{cpm}$ to 1.6 organisms/ $\mathrm{PMN}$; and in $\mathrm{P}^{-}$bacteria, $998.8 \mathrm{cpm}$ corresponded to 1.3 organisms/PMN and 1961.8 cpm to 2.2 organisms/PMN.

\section{DISCUSSION}

PMNs have been known to react predominantly against $C$. renale organisms in cows suffering from pyelonephritis [7, 16]. Therefore, phagocytosis of $\mathrm{P}^{+}$and $\mathrm{P}^{-}$bacteria of $C$. renale by PMNs was examined in the present study. $\mathrm{P}^{+}$bacteria were less phagocytized than $\mathrm{P}^{-}$bacteria in the absence of opsonins, and in the presence of anti- $\mathrm{P}^{-}$bacteria serum regardless of the presence of complement, but they were effectively phagocytized at a nearly equal rate to that of $\mathrm{P}^{-}$bacteria in the presence of anti-pili antiserum plus complement and anti- $\mathrm{P}^{+}$bacteria serum plus complement. The results suggest that anti-pili antibodies are almost solely important in the opsonization of $\mathrm{P}^{+}$bacteria. The anti-pili monoclonal antibodies $16 / 5$ and $13 / 4$ were also opsonic for $\mathrm{P}^{+}$bacteria, similar to anti-pili antiserum plus complement, but the opsonic effect was less than that of anti-pili antiserum plus complement.

Pili of $C$. renale may be resistant to phagocytic activity of PMNs, because $\mathrm{P}^{+}$ bacteria were always less phagocytized than $\mathrm{P}^{-}$bacteria in the absence of opsonins, as far as anti-pili antibodies were absent. A greater number of $\mathrm{P}^{+}$bacteria was phagocytized in the presence of anti-pili antibodies than that in the absence of anti-pili antibodies. These in vitro findings suggest that anti-pili antibodies might play an important role in host defense against infection of $C$. renale organisms which possess pili.
Anti-pili monoclonal antibodies $16 / 5$ inhibited the adhesion of $\mathrm{P}^{+}$bacteria to epithelial cells of the bovine vulva while $13 / 4 \mathrm{did}$ not [21]. Anti-pili monoclonal antibodies $16 / 5$ and $13 / 4$ were opsonic for $\mathrm{P}^{+}$bacteria. Uptake of $\mathrm{P}^{+}$bacteria in the presence of monoclonal antibody $16 / 5$ was not significantly different from that in the presence of monoclonal antibodies 13/4. Moreover, there was no difference in opsonic effect between the two monoclonal antibodies. A similar finding was observed in the experiment of phagocytosis of $C$. renale by macrophages [12]. Pili of $N$. gonorrhoeae had two epitopes, one was related to opsonization and the other was not. Pili of $C$. renale may have epitopes that are not related to opsonization. Further studies are needed to find such an epitope.

Phagocytosis by PMNs of $\mathrm{P}^{+}$and $\mathrm{P}^{-}$ bacteria shown in the present study and phagocytosis by macrophages of $\mathrm{P}^{+}$and $\mathrm{P}^{-}$ bacteria reported previously [12] are similar in the following points. i) $\mathrm{P}^{+}$bacteria were antiphagocytic to both PMNs and macrophages in the absence of opsonins. ii) Anti-pili antibodies were opsonic in phagocytosis $\mathrm{P}^{+}$bacteria by both $\mathrm{PMNs}$ and macrophages. iii) In the presence of anti-pili monoclonal antibodies, regardless of the presence of complement, $\mathrm{P}^{+}$bacteria were phagocytized both by PMNs and macrophages. iv) There were no differences between the opsonic effects of monoclonal antibodies 16/5 (adhesion-inhibitory) and $13 / 4$ (adhesion-non-inhibitory) in the phagocytosis of $\mathrm{P}^{+}$bacteria by both PMNs and macrophages. v) Uptake of $\mathrm{P}^{-}$bacteria by PMNs and macrophages was not enhanced in the presence of any antisera.

Phagocytosis by PMNs of $\mathrm{P}^{+}$and $\mathrm{P}^{-}$ bacteria shown in the present study and phagocytosis by macrophages of $\mathrm{P}^{+}$and $\mathrm{P}^{-}$ bacteria reported previously are different in the following points. i) The numbers of phagocytized $\mathrm{P}^{+}$and $\mathrm{P}^{-}$bacteria per $\mathrm{PMN}$ 
(1.6 and 4.1, respectively) were smaller than those phagocytized per macrophage (8.7 and 9.4, respectively [12]), examined in the absence of opsonins. ii) Anti-pili serum alone and anti- $\mathrm{P}^{+}$bacteria serum alone enhanced the uptake of $\mathrm{P}^{+}$bacteria by macrophages but not that by PMNs. iii) Anti-pili antibodies plus complement affected the phagocytosis of $\mathrm{P}^{+}$bacteria by PMNs sooner than that by macrophages. Maximum uptake of $\mathrm{P}^{+}$or $\mathrm{P}^{-}$bacteria by PMNs took $1 \mathrm{hr}$ while that by macrophages took $3 \mathrm{hr}$. A similar difference in the rapidity of phagocytosis between PMNs and monocytes was reported in E. coli, Staphylococcus aureus and Listeria monocytogenes [18].

Actinomyces viscosus and Actinomyces naeslundii possessing type 2 pili were more readily phagocytized than the bacteria lacking type 2 pili in the absence of opsonins by PMNs [20]. E. coli with type 1 pili also attached to PMNs and were more readily phagocytized than $E$. coli without type 1 pili in the absence of opsonins by PMNs $[1,13$, $14,21]$. The finding that $C$. renale $\mathrm{P}^{+}$ bacteria were less phagocytized than $\mathrm{P}^{-}$ bacteria in the absence of opsonins by PMNs was not similar to those of the actinomyces and $E$. coli. Piliated $H$. Influen$z a e$ type $\mathrm{b}$ was more readily phagocytized than non-piliated $H$. influenzae type $b$ in the presence of normal human serum (complement) by PMNs [22]. The finding that $C$. renale $\mathrm{P}^{+}$bacteria were less phagocytized than $\mathrm{P}^{-}$bacteria in the presence of complement by PMNs was not similar to those of $H$. influenzae. Piliated $N$. gonorrhoeae resisted phagocytosis in the absence of opsonins by PMNs $[2-4,19]$. The anti-PMNs property of piliated $N$. gonorrhoeae was similar to that of piliated $C$. renale. Another finding that piliated $N$. gonorrhoeae was phagocytized readily by PMNs in the presence of anti-pili serum [9] was also similar to that found in phagocytosis by PMNs of $C$. renale.

Studies are now under way to investigate phagocytosis by bovine PMNs of $\mathrm{P}^{+}$and $\mathrm{P}^{-}$ bacteria by PMNs derived from cows, the natural host.

REFERENCES

1. Björkstén, B., and Wadström, T. 1982. Interaction of Escherichia coli with different fimbriae and polymorphonuclear leukocytes. Infect. Immun. 38: 298-305.

2. Densen P., and Mandell, G. L. 1978. Gonococcal interactions with polymorphonuclear neutrophils: importance of the phagosome for bactericidal activity. J. Clin. Invest. 62: 1161-1171.

3. Dilworth, J. A., Hendley, J. O., and Mandell, G. L. 1975. Attachment and ingestion of gonococci by human neutrophils. Infect. Immun. 11: 512-516.

4. Gibbs, D. L., and Roberts, R. B. 1975. The interaction in vitro between human polymorphonuclear leukocytes and Neisseria gonorrhoeae cultivated in the chick embryo. J. Exp. Med. 141: 155-171.

5. Hiramune, T., Inui, S., Murase, N., and Yanagawa, R. 1971. Virulence of three types of Corynebacterium renale in cows. Am. J. Vet. Res. 32: $237-242$.

6. Honda, E., and Yanagawa, R. 1974. Agglutination of trypsinized sheep erythrocytes by the pili of Corynebacterium renale. Infect. Immun. 10: 1426-1432.

7. Inui, S. personal communication.

8. Jones, F. S., and Little, R. B. 1925. Specific infectious cystitis and pyelonephrilis of cows. $J$. Exp. Med. 42: 593-607.

9. Jones, R. B., Newland, J. C., and Buchanan, T. M. 1978. Opsonization of Neisseria gonrrhoeae: role of antipili antibody. Clin. Res. 26: 397 A.

10. Kabat, E. A., and Mayer, M. M. 1961. Complement and complement fixation. pp. 135-153. In: Experimental immunochemistry. 2nd ed. Charles C. Thomas. publisher.

11. Kudo, Y., Yanagawa, R., and Hiramune, T. 1987. Isolation and characterization of monoclonal antibodies against pili of Corynebacterium renale and Corynebacterium pilosum. Vet. Microbiol. 13: 75-85.

12. Kubota, T., and Yanagawa, R. 1987. Comparison of susceptibility to phagocytosis by mouse peritoneal macrophages between Corynebacterium renale piliated and non-piliated clones. Jpn. J. Vet. Sci. 49: 663-672.

13. Mangan, D. F., and Synder, I. S. 1979. Mannose- 
sensitive interaction of Escherichia coli with human peripheral leukocytes in vitro. Infect. Immun. 26: 520-527.

14. Mangan, D. F., and Synder, I. S. 1979. Mannosesensitive stimulation of human leukocyte chemiluminescence by Escherichia coli. Infect. Immun. 26: 1014-1019.

15. Okamoto, R., Takai, S., Yanagawa, R., and Sato, H. 1981. Isolation of non-piliated clone of Corynebacterium renale strain 115 . Jpn. J. Vet. Res. 29: 79-82.

16. Ono, Y. 1934. Pathogenesis of bacterial cystitis and pyelonephritis of cows. J. Sapporo Soc. Agric. For. 25: 299-355 (in Japanese).

17. Peterson, P. K., Verhoef, J., Sabath, L. D., and Quie, P. G. 1976. Extracellular and bacterial factors influencing Staphlococcal phagocytosis and killing by human polymorphonuclear leukocytes. Infect. Immun. 14: 496-501.

18. Peterson, P. K., Verhoef, J., Schmeling, D., and Quie, P. G. 1977. Kinetics of phagocytosis and bacterial killing by human polymorphonuclear leukocytes and monocytes. J. Infect. Dis. 136: 502-509.

19. Punsalang, A. P. Jr., and Sawyer, W. D. 1973.
Role of pili in the virulence of Neisseria gonorrhoeae. Infect. Immun. 8: 255-263.

20. Sandberg, A. L., Mudrick, L. L., Clsar, J. O., Brennan, M. J., Mergenhagen, S. E., and Vatter, A. E. 1986. Type 2 fimbrial lectin-mediated phagocytosis of oral Actinomyces spp. by polymorphonuclear leukocytes. Infect. Immun. 54: 472-476.

21. Silverblatt, F. J., Dreyer, J. S., and Schauner, S. 1979. Effect of pili on susceptibility of Escherichia coli to phagocytosis. Infect. Immun. 24: 218-223.

22. Tosi, M. F., Andeson, D. C., Barrish, J., Manson, E. O. Jr., and Kaplan, S. L. 1985. Effect of piliation on interactions of Haemophilus influenzae type $\mathrm{b}$ with human polymorphonuclear leukocytes. Infect. Immun. 47: 780-785.

23. Tsuji, Y., Hayashi, K., Maeda, H., and Yanai, M. 1984. Inspection method of function of polymorphonuclear leukocytes. Jpn. J. Clin Med. 42: (Suppl 510) 1375-1380 (in Japanese).

24. Virji, M., and Heckels, J. E. 1985. Role of anti-pili antibodies in host defense against Gonococcal infection studied with monoclonal antipilus antibodies. Infect. Immun. 49: 621-628.

要約

マウス好中球によるCorynebacterium renale 有線菌掞よび無線毛菌の食菌：窪田宜之・梁川 良（北海道大学 獣医学部家畜衛生学講座) —CCorynebacterium renale No. 115 株の有線毛 $\left(\mathrm{P}^{+}\right)$菌および無線毛 $\left(\mathrm{P}^{-}\right)$菌の マウス好中球による食菌を調べた。オプソニンの存在しない条件，5\%の補体のみ，あるいは抗線毛血清のみ， 抗 $\mathrm{P}^{+}$菌血清のみ，抗 $\mathrm{P}^{-}$菌血清のみのいずれかが存在する条件では， $\mathrm{P}^{-}$菌が $\mathrm{P}^{+}$菌より有意に多く食菌され た. $\mathrm{P}^{+}$菌の取り込みは，抗線毛血清と補体あるいは抗 $\mathrm{P}^{+}$菌血清と補体の存在下で上昇し， $\mathrm{P}^{-}$菌と同程度取 り込まれた．抗線毛単クローン性抗体16/15および13/4は補体の存否にかかわらず， $\mathrm{P}^{+}$菌に対しオプニソン効 果があり， $\mathrm{P}^{-}$菌に対してはなかった．抗線毛単クローン性抗体 $16 / 5$ と13/4のオプニソン効果は抗線毛血清と補 体の耐者が存在する場合よりも弱かった。 $\mathrm{P}$ 一菌の取り込みはオプニソンが存在する条件としない条件でほぼ同 じであった。またマウス好中球によるこれらの食菌の結果を以前報告したマウスマクロファージによる食菌の結 果と比較して考察した。 